\title{
Teaching Engineering Innovation, Design, and Leadership within a Community of Practice
}

\author{
Marnie Vegessi Jamieson and John M. Shaw \\ Department of Chemical and Materials Engineering, Faculty of Engineering, University of Alberta \\ mvjamies@ualberta.ca and jmshaw@ualberta.ca
}

\begin{abstract}
Process design is taught by instructors with a diverse mix of industrial and academic experience. The instructors work in close collaboration with working professional engineers including industrial technical specialists, entrepreneurs, and academic colleagues with an industrial focus to prepare unique process design projects and to advise student teams. Many of the industry advisors are long term contributors and over time some have been recruited as instructors for the design course. This community of practice offers students a window on engineering design practice and innovation as they transition to the professional community. This paper explores the contribution of the community of practice to student development, the achievement of the Canadian Engineering Accreditation Board (CEAB) graduate attributes, and the development of an innovation ecosystem.
\end{abstract}

Keywords: Community of Practice, Graduate Attributes, Design, Capstone, Student, Self, Outcomes, Course, Assessment, Communication, Innovation, Leadership, Blended Learning

\section{INTRODUCTION}

Student intellectual development is progressive and is necessary for them to meet performance criteria set out by the Canadian Engineering Accreditation Board graduate attributes (CEAB GA) [5], and to attain the capstone design course learning outcomes [11,12, 13,14]. The performance of criterion based tasks during the capstone design course requires students to have developed cognitive and affective domain skills at all levels of Bloom's taxonomy [4,11,14]. Integration of student intellectual and cognitive development into engineering program curricula may enhance student performance by supporting the creation and implementation of learning activities $[1,2,3,4,7,12$, $13,14,17,18]$. Teaching process and product design and leadership can be accomplished by constructing learning activities $[5,7,9,12,13,17$,$] in an experiential learning$ spiral [6] embedded in a contextual and supportive course structure or a situative learning framework or community of practice [20].

$\mathrm{CEAB}$ graduate attributes are not explicit regarding innovation, but at a minimum, they are implicit in the design, engineering tools, and communication graduate attributes. Here we pose the questions: can innovation skills be taught and can a metacognitive learning environment supported by a community of practice infuse an innovative spirit and leadership capacity?

\subsection{Literature Review}

Student development and learning can be enhanced with metacognitive strategies, feedback, engagement, and spaced practice [9]. Including these strategies throughout a program of study increases the use of spaced skill practice, and introduces students to technical and professional skills required to meet CEAB graduate attribute performance criteria earlier in their program of study. Cognitive learning frameworks $[7,12,18]$ support student knowledge acquisition and help students connect concepts in active learning environments. [3,7,11,18,] Students who develop selfconscious management of the learning process (metacognition) often perform better than those who do not [7]. A situative learning framework including student activities such as collaborative learning, leadership, task planning, and work strategies combined with iterative design processes can lead to metacognitive regulation functions and a recursive learning cycle or spiral $[6,9]$ where reflection leads to targeted practice that further develops technical, design, team, and leadership skills that transfer to new circumstances [12].

Innovation processes $[10,23]$ and effectuation thinking $[23,24]$ can be employed in design courses. This type of contextual learning is described by Lave [20] and Greeno, Collins \& Resnick [7] as the strengthening of the practices of the community and to be effective the learners must be offered legitimate peripheral participation [20]. Innovation requires thinking processes, goal setting, and strategies $[6,12$, $17,23,24,26]$ including effectuation thinking $[23,24,26]$. Effectuation describes a thinking process used when there is uncertainty and imagined solutions must be developed from the available means and within sets of constraints. The practice of innovation requires a situation where the development of the imagined ends is necessary $[6,17,26]$. It would appear that learning innovation requires legitimate participation in a community of practice where innovation is needed. 
Student participation in a community of practice may afford opportunities for them to develop innovation and leadership capabilities as suggested by the CEAB graduate attribute performance criteria.

\subsection{Motivation}

Innovation, design, and leadership are sought after traits in new engineering graduates and practitioners alike. The CEAB includes design, professionalism, and the ability to work as a leader on a team, as key engineering graduate attributes. Including innovation and leadership in undergraduate engineering programs of study is challenging given time constraints and the already ambitious learning outcomes for individual courses, and for the programs as a whole.

\subsection{Problem Definition}

Unique process design projects contributed by industrial and entrepreneurial sponsors change or are adapted from year to year, reflecting shifts in industrial focus and markets, and outcomes realized by student teams in prior iterations of the design course. These inputs foster and sustain an innovation ecosystem [17]. The criteria for final design report evaluation are performance based and do not change from year to year. However, incoming student populations and their learning needs do change from year to year. The course itself is evaluated following each iteration, in the spirit of continuous improvement, so that the overall achievement of course objectives can be improved over time. It is in this context that we endeavor to incubate and improve innovation, engineering design, and leadership skills among the students. The roles and potential importance of a community of practice, in the development and strengthening of students' skills in the practice of engineering is a topic that is often overlooked.

\subsection{Solutions Explored}

Here we explore the inclusion of innovation in design courses via alliances with industrial and engineering communities to form a community of practice where committed practicing engineers contribute projects and participate in the innovation process with students where new industrial and start-up opportunities are explored. Teaching evaluations, student engagement levels in the classroom, and evidence of student discussion as they make sense of materials and contextualize them are key indicators of success.

\subsection{Significance}

Student feedback has provided suggestions for improving skills such as technical reading, technical writing, and process or product design problem resolution earlier in their program of study. Working in teams earlier and more frequently, in their program of study, on goaloriented tasks was also cited as potentially advantageous to developing required skills for capstone design courses. Students have even purposefully formed and worked as teams in advance of the design courses to develop their team skills prior to the design courses. The student requests reflect a desire for earlier learning experiences that would help them develop skills related to the practice of engineering.

\subsection{EXPERIENTIAL LEARNING IN A SITUATIVE FRAMEWORK}

Undergraduate engineering curricula should provide opportunities for students to learn, practice, and demonstrate development of CEAB graduate attributes, and to reflect on progress and target the next steps to continue learning. The "ability to work as an effective team member or leader" does not simply develop as a result of listening to a lecture on either topic! It does not follow that knowledge of the principles of effective leadership makes someone an effective leader. The same could be said of becoming an effective innovator and designer. In addition, changing only the method of assessment to one that provides for performance demonstration without providing the opportunity to develop a skill with feedback is equally ineffective. The embedded nature of the learning space within a community of practice and the larger innovation ecosystem is situative $[6,7,10,11,16,17,18,19]$ in nature and Situativity Theory $[7,18,20]$ is the framework and context for this work.

The construction of learning activities by students in an environment where the learning objectives of a program of study are consistent with the required assessments and outcomes are central to the theory of constructive alignment $[3,7]$. Learning about learning and reflective strategies introduces students to and teaches them about team, design, and innovation processes $[1,2,7,12]$. A blended and active learning environment engages students in processes and encourages reflection and sense making [11,12]. A 
community of practice provides mentors and models of the innovation process, and an environment for students to be introduced to engineering design, innovation and leadership skills, and to develop and practice these skills.

\subsection{METHOD}

The Measurement of Scientific and Technological Activities Proposed Guidelines for Collecting and Interpreting Technological Innovation Data OSLO Manual (OSLO Manual) innovation map rehearsed in Figure 1 [21], illustrates factors necessary for innovation and informs innovation policy terrain at the international level. Measures of innovation possibility include the presence or absence of transfer factors from technological gatekeepers; to informal linkages among firms and regulatory and research agencies; to international links; to the ease of diffusion of information and ideas. This framework is adapted to the capstone process design course community of practice environment where for engineering design, innovation can be more narrowly defined and can be measured based on objective improvement in the performance of a process or a product [21]. Schumpeter [25] suggests "radical" innovations shape big changes in the world, whereas "incremental" innovations fill in the process of change continuously. Process innovation, new to an industry, is one of the key drivers for economic change [21,27].

In this study, projects proposed by members of the community of practice are classified as: innovation, if the project required a process innovation to complete a design; efficiency, if the project required a comparison or incremental improvement; or benchmark, if the process design was based on completing an already operating design. Our measure of innovation in the course includes the number of design projects that produce either a process or a product innovation, that propose an innovative process, that capture $R \& D$ in the design, or offer a fresh perspective on an old problem. The degree of innovation demonstrated in student design reports is not evaluated in this preliminary analysis. Examples of innovation projects include pre FEED (Front End Engineering Design) level conceptual designs for a pilot, demonstration or full-scale process from $\mathrm{R} \& \mathrm{D}$ or a process patent, and new technology options for old process problems. Efficiency projects included comparisons for incremental improvements or for modifications to existing facilities to improve efficiencies or to modify production rates. Benchmarking projects included pre FEED level designs of standard technologies already in commercial use. While not captured in this contribution, design reports submitted by students may include product or process innovations irrespective of proposed project classification.

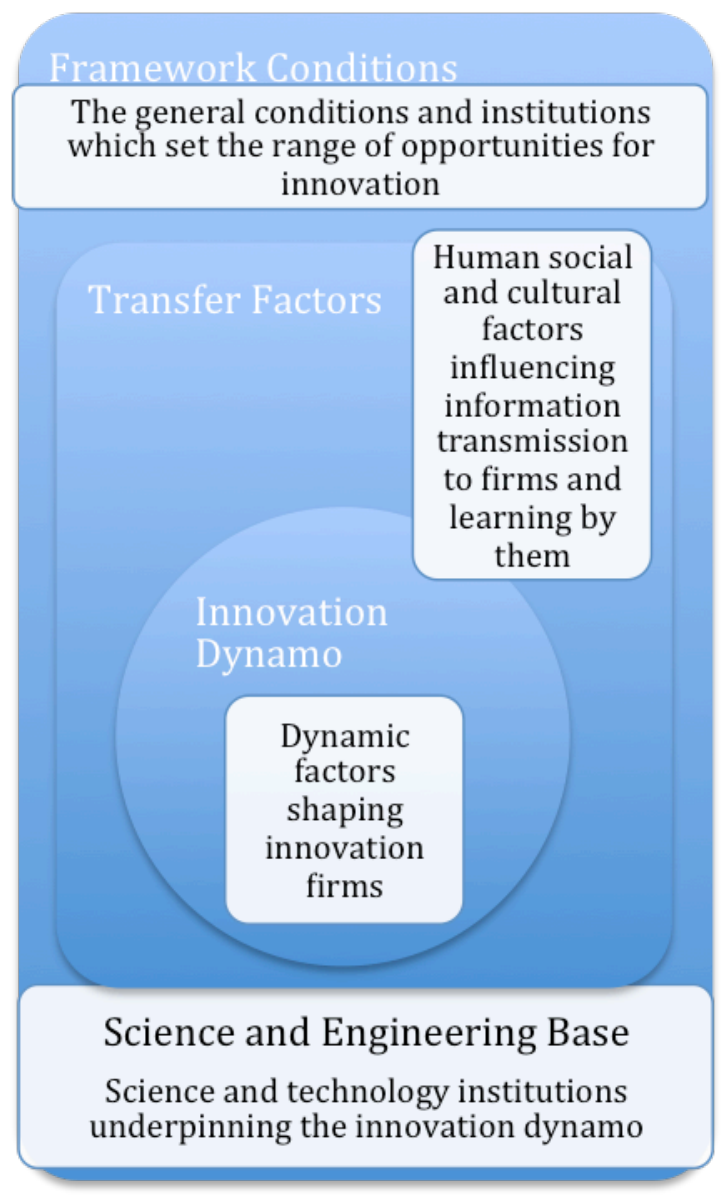

Figure 1. Innovation Policy Map - OSLO

\subsection{RESULTS AND DISCUSSION}

The industrial advisor proposed capstone process design projects for the past decade are classified in Figure 2. Twenty-five to thirty-five projects are proposed annually as shown in Table 1. The changes in the percentage of projects 


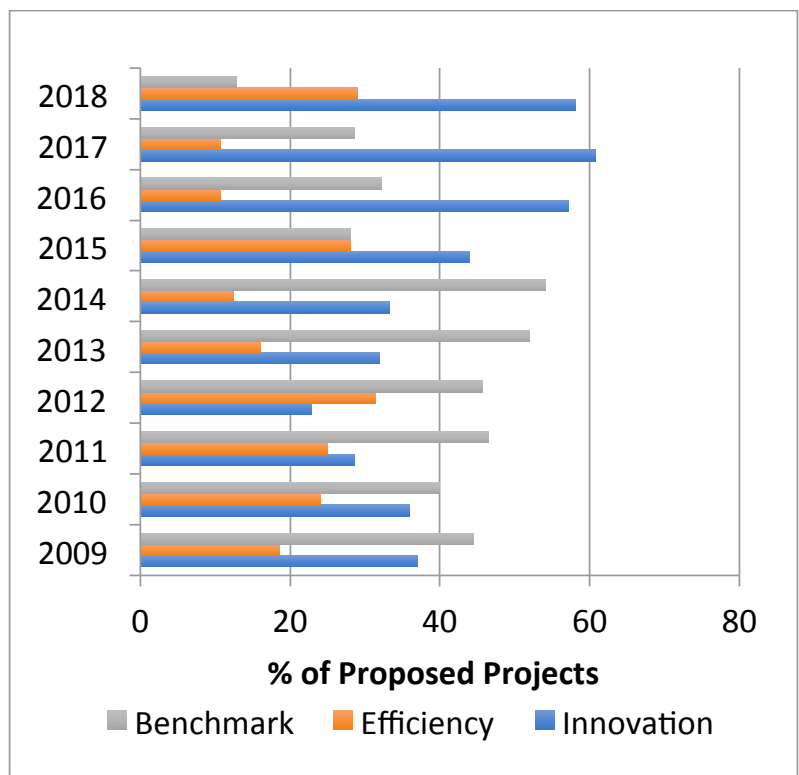

Figure 2. Project Classification by Year.

Table 1. Annual Number of Proposed Projects

\begin{tabular}{|c|c|c|c|}
\hline \multirow{2}{*}{ Year } & \multirow{2}{*}{$\begin{array}{c}\text { Proposed } \\
\text { Projects }\end{array}$} & \multicolumn{2}{|c|}{ Advisor Classification } \\
\cline { 3 - 4 } & & Returning & New \\
\hline 2018 & 31 & 22 & 10 \\
\hline 2017 & 28 & 19 & 9 \\
\hline 2016 & 28 & 20 & 8 \\
\hline 2015 & 25 & 16 & 9 \\
\hline 2014 & 24 & 12 & 12 \\
\hline 2013 & 25 & 17 & 8 \\
\hline 2012 & 35 & 18 & 17 \\
\hline 2011 & 28 & 14 & 14 \\
\hline 2010 & 25 & 15 & 10 \\
\hline 2009 & 27 & 14 & 13 \\
\hline
\end{tabular}

requiring process innovation over time may reflect changes in the business needs of the community of practice over time and the selection of new advisors from different sectors over time leading to a shift in the composition and focus of the community of practice. For example, prior to 2010 , two instructors taught the course and managed the project proposal process with a largely corporate industry advisor base. Many advisors were interested in evaluating potential recruits. Benchmark projects were common and were more easily assessed by both instructors, who guided up to twelve teams each, and industrial advisors.

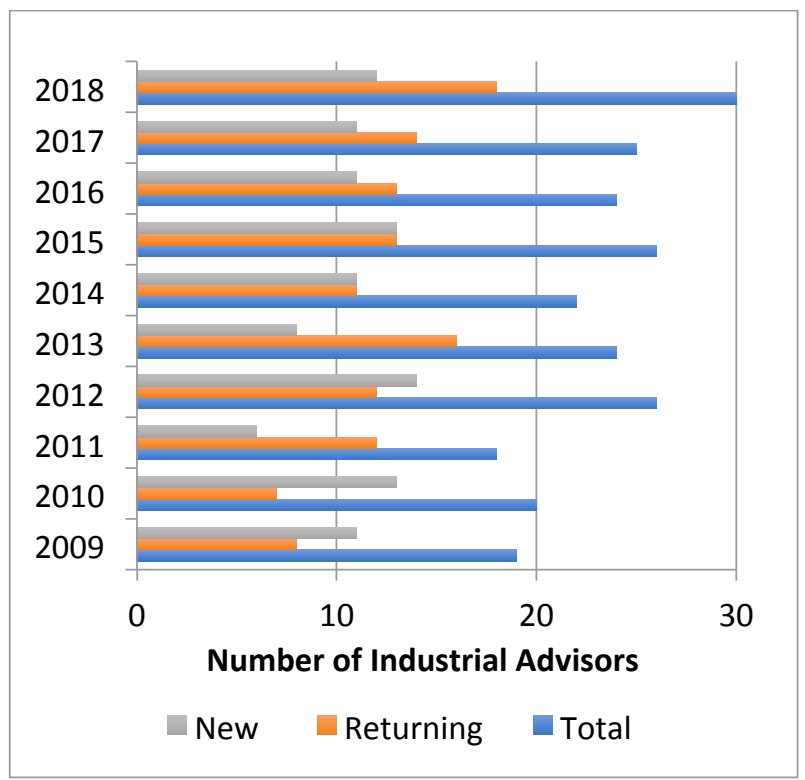

Figure 3. Industrial Advisor Classification by Year

Between 2010 and 2012, there were three instructors. In 2014 there were four instructors and since 2015, there have been five instructors. The increase in the number of instructors with time reflects both the growing enrolment and the intensification of resources in design education.

The number of industrial advisors, coded as new or returning is presented in Figure 3. Some returning advisors elect to advise two or in exceptional circumstances three student teams. Conversely advisors may propose multiple projects but only advise one project. Most but not all of the proposed projects are selected by student teams. Returning advisors often invite new advisors to join them in advising student teams. These new advisors often return to advise teams in subsequent iterations of the course.

The number of projects proposed by new and returning advisors is shown in Table 1. The percentage of proposed projects requiring an innovative response has increased sharply since 2015, for new advisors, and 2016, for returning advisors, as shown in Figures 4 and 5. This change is due in part to changing economic circumstances and a shift in the priorities of the community of practice. From 2010 to 2014 new and returning advisors were more likely to propose benchmark or efficiency projects. The increase in the number of instructors also enabled the course instructors to 
support more projects requiring process innovation. Innovation projects require more instructor and industry advisor support than benchmark projects. In 2015 the blended learning was introduced into the design course $[11,12$, $13,14]$. Blended learning changed the dynamics of the instructor student interactions; the engagement of the students with their industry advisors and the design projects themselves. These coincident shifts all enhanced transfer factors and the innovation dynamo [21, 27] in the process design community of practice.

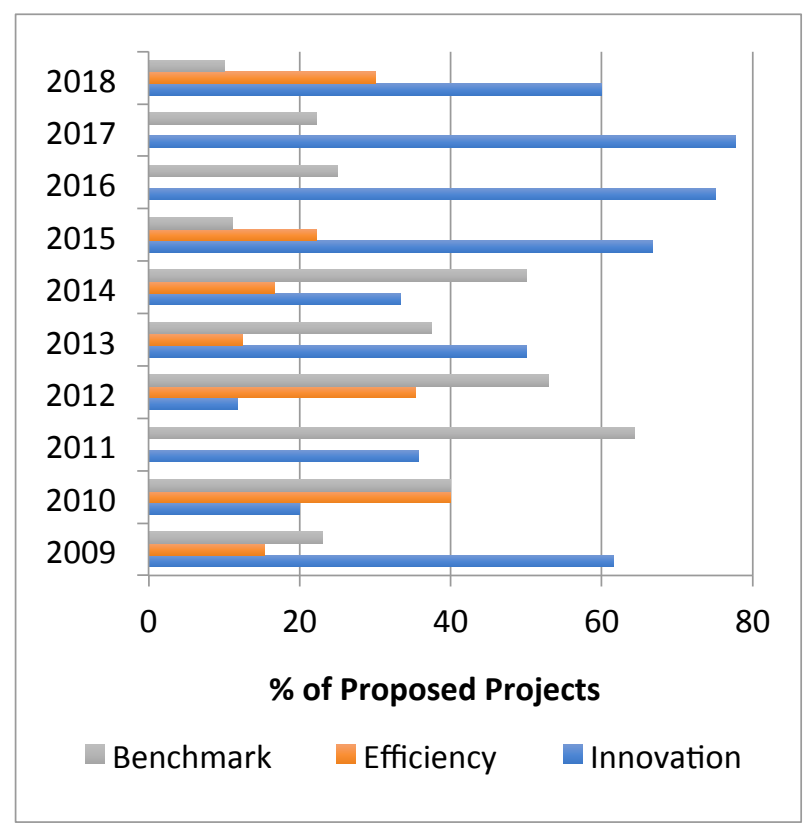

Figure 4. Classification of Projects Proposed by New Industrial Advisors by year

The design course community of practice structure can be superimposed on the more general OSLO innovation policy map (Figure 1) and is presented as Figure 6. The key factors contributing to the innovation dynamo, in general, include innovation process capacity, skilled employees, alliances, and innovation options. In the design course, the innovation dynamo comprises the student teams, teaching assistants, academic and industrial advisors and the course structure that fosters learning and targeted skill development. Teams use metacognitive cycles to reflect on their overall performance monthly and on their learning performance weekly. Performance is directly tied to the $\mathrm{CEAB}$ graduate attributes. The design course transfer factors are expressed as the formal and informal linkages between industrial advisors, the university research community, and the student design teams. The industrial advisors include representatives from regulatory, entrepreneurial, research and innovation, consulting, oil and petrochemical production, and engineering, procurement, and construction (EPC) sectors, drawn from local, national, and international engineering communities. This diversity facilitates the mobility of new ideas. Both industrial and academic advisors may act as technological

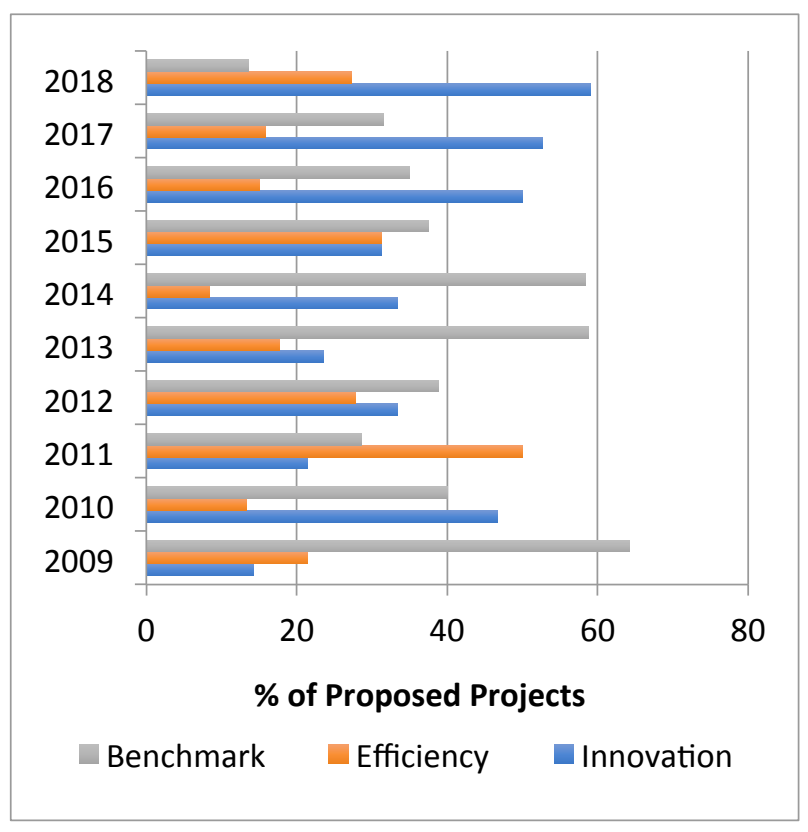

Figure 5. Classification of Projects Proposed by Returning Industrial Advisors by year

gatekeepers by keeping abreast of new developments and seeking out new connections and opportunities for the community. The community of practice values trust and is regulated with IP agreements where appropriate. Reworking and redeveloping projects to achieve better results over time also supports innovation and is a part of the business development cycle managed by the course instructors.

\subsection{CONCLUSIONS}

The process design course community of practice has changed over time and the motivation for participation in the community has shifted from 


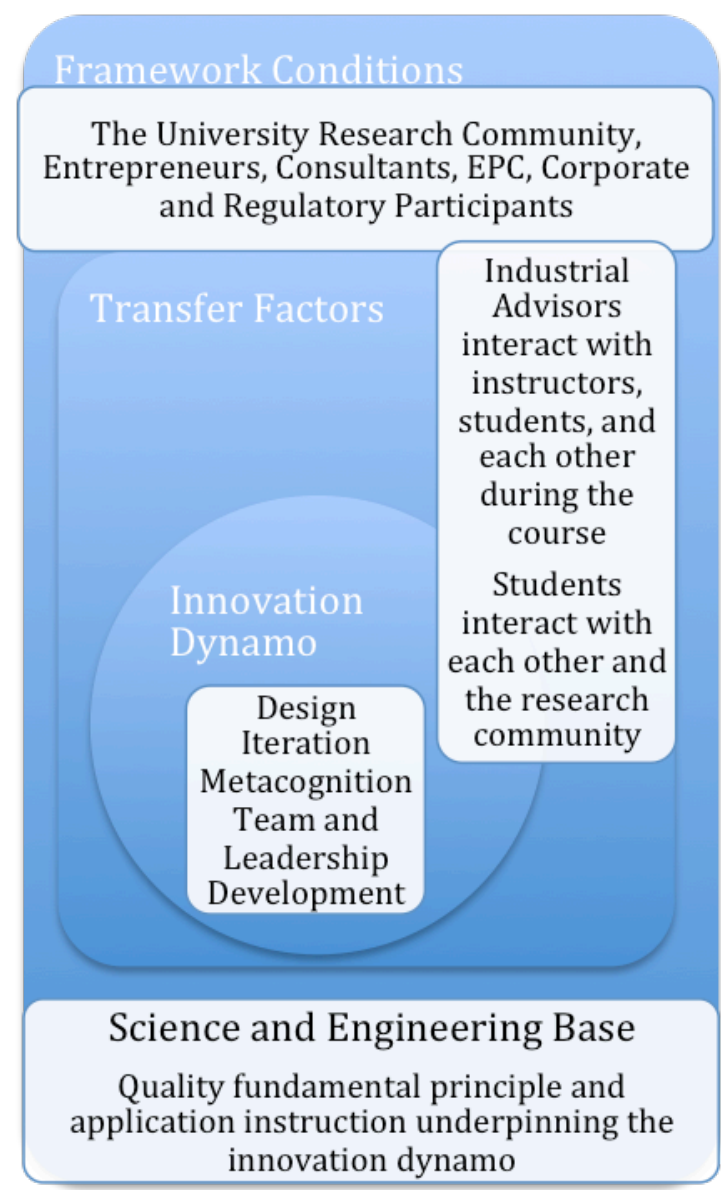

Figure 6. Innovation Policy Outline Map - Comparison to Capstone Community of Practice Structure

benchmarking competence to innovation competence that supports student innovation and leadership capacity development. The increase in number of instructors has facilitated this shift as has the change from a lecture format to a blended learning course delivery format. The opportunity to strengthen design, leadership, and innovation skills within a community of practice is illustrated. In a future study we will report on student responses to this opportunity as demonstrated in their final design reports and in CEAB GA survey data as examined through the lens of the innovation dynamo.

\section{Acknowledgements}

The design course redevelopment was funded by the Provost's Office (University of Alberta). The CTL blended learning research project, of which this research is a part, received research ethics approval from the University of Alberta Research Ethics Board, No. Pro00048272. The authors acknowledge with thanks the support given by our community of practice - our students, our teaching team, our research community, and our industry participants.

\section{REFERENCES}

[1] Ken Bain, What the Best College Teachers Do. Cambridge, Mass.: Harvard University Press 2004. \{ISBN: 9780674013254\}

[2] John C. Bean, Engaging Ideas: The Professor's Guide to Integrating Writing, Critical Thinking, and Active Learning in the Classroom. $2^{\text {nd }}$ ed. Jossey Bass : San Francisco, 360 p. 2011. \{ISBN: 978-0-470-53294-4\}

[3] John Biggs, What the student does: teaching for enhanced learning, Higher Education and Development 18(1):57-75, 1999.

[4] B. Bloom, M. Englehart, E. Furst, W. Hill, \& D. Krathwohl Taxonomy of educational objectives: The classification of educational goals. Handbook I: Cognitive domain. New York, Toronto: Longmans, Green 1956.

[5] Canadian Engineering Accreditation Board, "Canadian Engineering Accreditation Board: Accreditation Criteria and Procedures", Ottawa: Canadian Council of Professional Engineers, 2014. Accessed June 20, 2015.

[6] Peter Drucker,"The Discipline of Innovation," Harvard Business Review, 1985.

[7] J. Greeno, A. Collins, \& L. Resnick, Cognition and Learning. In R. Calfee \& D. Berliner (Eds.), Handbook of educational psychology (pp. 15-46). New York, NY: MacMillan, 1996.

[8] M. Henton, Adventure in the Classroom: Using Adventure to Strengthen Learning and Build a Community of Life-long Learners. Dubuque, Iowa: Kendall/Hunt. (1996).

[9] John Hattie, "The Black Box of Tertiary Assessment: An Impending Revolution". in L. H. Meyer, S. Davidson, H. Anderson, R. Fletcher, P.M. Johnston, \& M. Rees (Eds.), Tertiary Assessment \& Higher Education Student Outcomes: Policy, Practice \& Research (pp.259-275). Wellington, New Zealand: Ako Aotearoa 2009.

[10] T. Ito, T. Ichikawa, N.C. Hanumara, A. H. Slocum Teaching Creativity in Design Through Project-Based Learning in a Collaborative Distributed Educational Setting. In: Schaefer D. (eds) Cloud-Based Design and Manufacturing (CBDM). Springer, Cham, 2014.

[11] Marnie V. Jamieson, "Application of Blended and Active Learning to Chemical Engineering Design 
Instruction", University of Alberta (2016)

[12] Marnie V. Jamieson and John M. Shaw, "Applying metacognitive strategies to teaching engineering innovation, design, and leadership," in Proc. 2017 Canadian Engineering Education Conf. (CEEA17), G. Evans (ed)(Toronto, Ontario; 4-7 June 2017), Paper 045

[13] Marnie V. Jamieson and John M. Shaw, "Online Learning Element Design - Development and Application Experiences," Proc. 2016 Canadian Engineering Education Association (CEEA16) Conf. Paper 038 Dalhousie University; June 19 - 22, 2016.

[14] Marnie V. Jamieson and John M. Shaw, "Pre and Post Course students self assessment of CEAB Graduate Attributes - A Tool for Outcomes Assessment, Student Skill and Course Improvement," Proc. 2016 Canadian Engineering Education Association (CEEA16) Conf. Paper 037 Dalhousie University; June 19 - 22, 2016.

[15] Marnie V. Jamieson and John M. Shaw, “Team Midterm in an Introductory Process Design Course," Proc. 2016 Canadian Engineering Education Association (CEEA16) Conf. Paper 036 Dalhousie University; June 19 - 22, 2016.

[16] Marnie V. Jamieson, Leah Goettler, Albert Liu, and John M. Shaw, "To Teach is to Learn: Student and Instructor Perspectives on Assignment Development as a Springboard to Deep Learning," in Proceedings of the 13th International CDIO Conference, Calgary, Canada, 18-22, June, 2017

[17] Steve Johnson, Where Good Ideas Come From: The Natural History of Innovation, Riverhead Trade, 2011. Chapter 1: "Reef, City, Web: Darwin's paradox"

[18] Aditya Johri \& Barbara M. Olds, Situated Engineering Learning: Bridging Engineering Education Research and the Learning Sciences. Journal of Engineering Education, 100(1), 151-1852011.
[19] Alice Y. Kolb \& David A. Kolb, The Learning Way: Meta-cognitive Aspects of Experiential Learning. Simulation \& Gaming, 40(3), 297-327 2009.

[20] Lave, J., \& Wenger, E. Situated learning: Legitimate peripheral participation. Cambridge, UK: Cambridge University Press. 1991.

[21] Oslo manual. [electronic resource] : guidelines for collecting and interpreting technological innovation data. n.p.: Paris : Organisation for Economic Co-operation and Development : Statistical Office of the European Communities, 2005., 2005. University of Alberta Library, EBSCOhost (accessed February 11, 2018).

[22] L. Resnick, \& L. Klopfer, (Eds.) Toward the Thinking Curriculum: Current Cognitive Research, 1989. Alexandria, VA: Association for Supervision and Curriculum Development.

[23] S. Sarasvathy, \& S. Venkataraman, "What Makes Entrepreneurs $\quad$ Entreprenurial?”, 2001. http://www .effectuation.org/paper/what-makesentrepreneurs-entrepreneurial

[24] S. Sarasvathy, \& S. Venkataraman, "Entrepreneurship as Method: Open Questions for an Entrepreneurial Future," Entrepreneurship Theory and Practice. 35, No. 1: p. 113-135.

[24] J. Schumpeter, The Theory of Economic Development, Harvard University Press, Cambridge, Massachusetts 1934.

[26] Amy Wilkinson, The Creator's Code, Simon \& Schuster: New York, NY, 2015.

[27] WIPO. Lhuillery Stéphane, Julio Raffo, and Intan Hamdan-Livramento, Economic Research Working Paper No. 31, Measuring Creativity: Learning from Innovation Measurement. World Intellectual Property Organization, Geneva, 2016. 